\title{
Cerebral Meningioma
}

National Cancer Institute

\section{Source}

National Cancer Institute. Cerebral Meningioma. NCI Thesaurus. Code C4807.

A meningioma that affects the cerebral hemispheres. 